\title{
THE RECOVERY OF CLINICALLY IMPORTANT ANAEROBES ON SOLID MEDIA
}

\author{
B. WATT \\ Department of Bacteriology, University Medical School, Edinburgh
}

IT was shown by Collee, Rutter and Watt (1971) that the difficulties encountered in the surface culture of Clostridium oedematiens (Cl. novyi) types B and D can be overcome by the use of modified Moore's medium (Moore, 1968) or by sprinkling sterile iron filings on the surface of a seeded blood agar plate. This approach made it possible to study quantitatively whether the growth was derived from spores or from vegetative cells. It was found for type D of this exacting organism that vegetative cells can account for an appreciable part of the growth obtained when a broth culture is subcultured on solid medium. This finding may be of practical importance also in the case of other anaerobes. It raises the question whether the traditional methods give adequate recovery of anaerobic organisms for clinical purposes or whether more elaborate procedures such as those of Hungate (1950) and Drasar and Crowther (1971) should be employed.

\section{MATERIALS AND METHODS}

Strains. The following test strains were subcultured in cooked-meat broth (CMB): Clostridium oedematiens ( $\mathrm{Cl}$. novyi) type A, NCTC no. 538; $\mathrm{Cl}$. oedematiens type B, Glaxo no. 474E; $C l$. welchii ( $C l$. perfringens) type $\mathrm{A}, \beta$-haemolytic, non-heat-resistant strain, no. 1BW; Cl. welchii type A, non-haemolytic, heat-resistant strain, no. 2BW; Cl. tetani type VI, NCTC no. 9567; Cl. histolyticum, NCTC no. 503; $\mathrm{Cl}$. septicum, no. $101 ; \mathrm{Cl}$. septicum, no. 114; Cl. bifermentans, NCTC no. 506; anaerobic coccus (group I), NCTC no. 9801; Bacteroides fragilis, NCTC no. 9343; Bact. necrophorus, NCTC no. 10575.

The following organisms were subcultured in nutrient broth after isolation from clinical material and identification: two strains of Staphylococcus aureus; one strain of Streptococcus pyogenes (group A), one strain of Bacillus anthracoides; one strain of Neisseria gonorrhoeae; one strain of Veillonella sp.; and two strains of Haemophilus influenzae.

Media. Cooked-meat broth was prepared as described by Cruickshank (1968, p. 757), but the infusion broth component was made from Nutrient Broth no. 2 (Oxoid). Oxoid Nutrient Broth was also used for the subculture of some of the test organisms. "Presteamed nutrient broth " was used as a diluent in the quantitative studies; it was heated by steaming at $100^{\circ} \mathrm{C}$ for $30 \mathrm{~min}$. to remove dissolved air, then cooled rapidly to $37^{\circ} \mathrm{C}$.

In the initial studies, Watt's modification of Moore's medium (cysteine-dithiothreitol human blood agar) was used (Collee et al.). In later studies, a further modification (cysteinedithiothreitol equine blood agar was prepared by substituting 10 per cent. horse blood for 33 per cent. human blood.

Blood agar plates were prepared with Oxoid Blood Agar Base no. 2 enriched with equine blood (10 per cent.) or human blood (33 per cent.).

Blood. Outdated citrated human blood was obtained from the Blood Transfusion Department, Edinburgh Royal Infirmary. Defibrinated equine blood was supplied by Wellcome Laboratories.

Received 11 Aug. 1971; accepted 21 Oct. 1971.

J. MED. MICROBIOL.-VOL. 5 (1972)

211 
Anaerobic culture procedure. In the present studies, anaerobic jars with room-temperature catalyst sachets (Baird and Tatlock) were used. One catalyst sachet was used for each jar. The detailed procedure for the setting up of the anaerobic jars (hydrogen 90 per cent., carbon dioxide 10 per cent.) has already been described by Collee et al. All culture media were incubated at $37^{\circ} \mathrm{C}$.

Gases. Cylinders of carbon-dioxide gas were supplied by Distillers Company Ltd; compressed hydrogen was obtained from British Oxygen Co. Ltd.

Counting methods. Total counts of bacteria and of spores were performed with a Hawksley counting chamber of $0.1 \mathrm{~mm}$ depth (BS 748). Counts were made with phase-contrast microscopy; at least 400 bacteria were counted and the results of two or more independent counts by two observers were collated for each experiment. The bacteria were allowed to settle in the counting chamber for 5-10 min. before counting. Fuller details are given elsewhere (Collee et al.). Spore estimates were checked by observations of smears stained by Ashby's malachite-green procedure (Cruickshank, p. 657) and by Gram's method.

Viable counts were performed by the spread-plate method, surface counts being derived from 0.02- $\mathrm{ml}$ inocula dropped from standard calibrated Pasteur pipettes and spread in a standard manner with sterile glass spreaders of uniform dimensions. The inocula were derived from parent cultures at specified dilutions in pre-steamed nutrient broth.

Surface viable counts were calculated from the mean result obtained with at least two plates for a given dilution; the dilution chosen was that giving 100-700 discrete colonies per plate.

Heating. Culture samples were held in pre-heated bijou bottles totally immersed in a waterbath at $70^{\circ} \mathrm{C}$ or $80^{\circ} \mathrm{C}$ for $20 \mathrm{~min}$., as specified in the text, and were than rapidly cooled to temperatures below $50^{\circ} \mathrm{C}$ in running water at a temperature of $16-18^{\circ} \mathrm{C}$.

Iron filings. Crude iron filings were obtained from local laboratory stock and sterilised by autoclaving.

Antisera. An experimental $\mathrm{Cl}$. septicum antitoxic serum no. Ex3567 kindly given to Dr J. G. Collee by Wellcome Research Laboratories, was used to inhibit the spreading of Cl. septicum strains. This serum was one of many used in toxin-antitoxin neutralisation tests. In a series of experiments analogous to those described for $\mathrm{Cl}$. tetani by Williams and Willis (1970), Cl. septicum serum no. Ex3567 was found to be effective in controlling the spreading growth of the test strains of $C l$. septicum when $0.1 \mathrm{ml}$ of the undiluted serum was spread on the surface of a well-dried blood agar plate before seeding.

\section{RESULTS}

\section{Determination of the significantly viable particle}

The nine test strains of clostridia comprised representative strains of $\mathrm{Cl}$. oedematiens, type A; Cl. oedematiens, type B; $\beta$-haemolytic, non-heat-resistant $\mathrm{Cl}$. welchii, type $\mathrm{A}$; non-haemolytic, heat-resistant $\mathrm{Cl}$. welchii, type $\mathrm{A} ; \mathrm{Cl}$. tetani, type VI; Cl. septicum (two strains); Cl. histolyticum and Cl. bifermentans. All grew readily in cooked-meat broth (CMB). When subcultured on to the surface of equine blood agar (EBA) or cysteine-dithiothreitol equine blood agar (CDEBA), consistent growth and easily visible colonies were obtained after overnight incubation, so that reliable surface counts could be performed. In the case of $\mathrm{Cl}$. septicum, spreading of the growth was avoided by the use of antitoxin-spread plates. Regular checks of identity and purity were made on aerobically and anaerobically incubated media.

The surface viable counts of the test strains of clostridia always exceeded the total number of spores present, sometimes by more than 100 -fold. When the number of spores was low, as in the case of young (5-hr) CMB cultures, the discrepancy between the total viable count and the estimated number of spores 
was readily demonstrated (tables I-IV). For example, in the case of a nonresistant strain of $\mathrm{Cl}$. welchii, viable counts of the order of $5 \times 10^{7}$ organisms per $\mathrm{ml}$ were obtained from inocula containing less than $6.6 \times 10^{4}$ spores per $\mathrm{ml}$. In many cases, a considerable diminution in surface count was observed after mild pasteurisation of the sample at $70^{\circ} \mathrm{C}$ for $20 \mathrm{~min}$., or after heating to $80^{\circ} \mathrm{C}$

TABLE I

Viability of duplicate samples of 5-hr CMB cultures of two test strains of Clostridium welchii on different media before and after heating at $70^{\circ} \mathrm{C}$ and $80^{\circ} \mathrm{C}$

\begin{tabular}{|c|c|c|c|c|c|}
\hline \multirow{2}{*}{$\begin{array}{l}\text { Test } \\
\text { strain }\end{array}$} & \multirow{2}{*}{$\begin{array}{l}\text { Treatment of } \\
\text { sample }\end{array}$} & \multicolumn{4}{|c|}{ Surface viable counts per $\mathrm{ml}$ on } \\
\hline & & EBA $\ddagger$ & EBAIF $\ddagger$ & CDEBA $\ddagger$ & CDEBAIF $\ddagger$ \\
\hline $\begin{array}{c}C l \text {. welchii } \\
\text { Type A: } \\
\text { non-heat- } \\
\text { resistant } \\
\text { strain } \\
1 \mathrm{BW}\end{array}$ & $\begin{array}{l}\text { Nil } \\
\text { Heated at } 70^{\circ} \mathrm{C} \\
\text { for } 20 \mathrm{~min} \text {. } \\
\text { Heated at } 80^{\circ} \mathrm{C} \\
\text { for } 20 \mathrm{~min} .\end{array}$ & $\begin{array}{c}(6 \cdot 5-6 \cdot 7) \times 10^{7} \\
<10 \S,<10 \\
<10,<10\end{array}$ & $\begin{array}{c}(4 \cdot 9-6 \cdot 1) \times 10^{7} \\
<10,<10 \\
<10,<10\end{array}$ & $\begin{array}{c}(5 \cdot 9-6 \cdot 0) \times 10^{7} \\
<10,<10 \\
<10,<10\end{array}$ & $\begin{array}{c}(4 \cdot 9-5 \cdot 4) \times 10^{7} \\
<10,<10 \\
<10,<10\end{array}$ \\
\hline $\begin{array}{c}C l \text {. welchii } \\
\text { Type A: } \\
\text { heat- } \\
\text { resistant } \\
\text { strain } \\
2 \mathrm{BW} \dagger\end{array}$ & $\begin{array}{l}\text { Nil } \\
\text { Heated at } 70^{\circ} \mathrm{C} \\
\text { for } 20 \mathrm{~min} \text {. } \\
\text { Heated at } 80^{\circ} \mathrm{C} \\
\quad \text { for } 20 \mathrm{~min} \text {. }\end{array}$ & $\begin{array}{l}(6 \cdot 1-6 \cdot 4) \times 107 \\
\quad<10,<10 \\
<10,10\end{array}$ & $\begin{array}{c}(5 \cdot 9-6 \cdot 9) \times 10^{7} \\
10-70 \\
10-30\end{array}$ & $\begin{array}{c}(5 \cdot 3-5 \cdot 9) \times 10^{7} \\
<10,10 \\
10-20\end{array}$ & $\begin{array}{c}(5 \cdot 9-6 \cdot 0) \times 107 \\
30-40 \\
20-70\end{array}$ \\
\hline
\end{tabular}

* The total cell count was $1.1 \times 10^{8}$ per ml; the spore estimate was $<6.6 \times 10^{4}$ per ml. (No spores seen in over 1700 cells counted.)

$\dagger$ The total cell count was $6.6 \times 10^{7} \mathrm{per} \mathrm{ml}$; the spore estimate was $<6.6 \times 10^{4} \mathrm{per} \mathrm{ml}$. (No spores seen in over 1000 cells counted.)

$\ddagger \mathrm{EBA}=10$ per cent. equine blood agar; $\mathrm{EBAIF}=\mathrm{EBA}$ sprinkled with iron filings; CDEBA = EBA supplemented with cysteine and dithiothreitol; CDEBAIF = CDEBA sprinkled with iron filings.

$\S$ No growth obtained from $0 \cdot 1 \mathrm{ml}$ of an undiluted sample.

for $20 \mathrm{~min}$. These findings strongly suggest that vegetative cells were the significantly viable particles in young (5-hr) cultures.

With the $\mathrm{Cl}$. septicum strains, the spreading surface growth rendered accurate colony counting difficult. This was controlled by a procedure based on that of Willis and Williams (1970): well-dried plates were treated with a selected Cl. septicum antitoxin before they were seeded (see Materials and methods). It was then possible to show that considerably more organisms were recovered than could be accounted for by the estimated number of spores in the inoculum (table II). An incidental finding with this strain is that a proportion of the estimated spore population survived heating at $70^{\circ} \mathrm{C}$ but not at $80^{\circ} \mathrm{C}$ for $20 \mathrm{~min}$.

In the case of $\mathrm{Cl}$. tetani (table III), the quantitative studies were performed with a non-motile type VI strain. Growth from vegetative cells greatly exceeded the total number of spores. For example, surface viable counts of $2-4 \times 10^{5}$ 
organisms per $\mathrm{ml}$ were obtained from cultures in which the estimated number of spores was less than $6.6 \times 10^{3}$ per ml.

TABLE II

Viability of duplicate samples of a 5-hr CMB culture of Clostridium septicum (strain 101)* on different media before and after heating at $70^{\circ} \mathrm{C}$ and $80^{\circ} \mathrm{C}$

\begin{tabular}{l|c|c|c|c}
\hline \multirow{2}{*}{$\begin{array}{c}\text { Treatment } \\
\text { of sample }\end{array}$} & \multicolumn{4}{|c}{ Surface viable counts per ml on } \\
\cline { 2 - 5 } & EBA $\ddagger$ & EBAIF $\ddagger$ & CDEBA $\ddagger$ & CDEBAIF $\ddagger$ \\
\hline Nil & $(2 \cdot 1-2 \cdot 5) \times 10^{6}$ & $(1 \cdot 8-2 \cdot 1) \times 10^{6}$ & $(2 \cdot 4-3 \cdot 2) \times 10^{6}$ & $(1 \cdot 9-2 \cdot 0) \times 10^{6}$ \\
$\begin{array}{l}\text { Heated at } 70^{\circ} \mathrm{C} \text { for } \\
20 \mathrm{~min} .\end{array}$ & $(3 \cdot 5-3 \cdot 7) \times 10^{3}$ & $(3 \cdot 2-3 \cdot 7) \times 10^{3}$ & $(4 \cdot 4-4 \cdot 9) \times 10^{3}$ & $(4 \cdot 1-4 \cdot 5) \times 10^{3}$ \\
$\begin{array}{l}\text { Heated at } 80^{\circ} \mathrm{C} \text { for } \\
20 \mathrm{~min} .\end{array}$ & $<10 \S,<10$ & $<10,<10$ & $<10,<10$ & $<10,<10$ \\
\hline
\end{tabular}

* The total cell count was $1.2 \times 10^{7}$ per $\mathrm{ml}$; the spore estimate was $3.5 \times 10^{5}$ per ml.

$\dagger$ All plates spread with $0 \cdot 1 \mathrm{ml}$ antitoxin (Cl. septicum Ex3567) before inoculation.

$\$ \mathrm{EBA}=10$ per cent. equine blood agar; EBAIF = EBA sprinkled with iron filings; $\mathrm{CDEBA}=\mathrm{EBA}$ supplemented with cysteine and dithiothreitol; $\mathrm{CDEBAIF}=\mathrm{CDEBA}$ sprinkled with iron filings.

$\S$ No growth from $0.1 \mathrm{ml}$ of an undiluted sample.

TABLE III

Viability of duplicate samples of a 5-hr CMB culture of Clostridium tetani type VI* on different media before and after heating at $70^{\circ} \mathrm{C}$ and $80^{\circ} \mathrm{C}$

\begin{tabular}{l|c|c|c|c}
\hline \multirow{2}{*}{$\begin{array}{c}\text { Treatment } \\
\text { of sample }\end{array}$} & \multicolumn{4}{|c}{ Surface viable count per ml on } \\
\cline { 2 - 5 } & EBA $\dagger$ & EBAIF $\dagger$ & CDEBA $\dagger$ & CDEBAIF† \\
\hline Nil & $\begin{array}{c}(2 \cdot 8-3 \cdot 0) \times 10^{5} \\
<10 \ddagger,<10\end{array}$ & $\begin{array}{c}(1 \cdot 8-2 \cdot 2) \times 10^{5} \\
<10,<10\end{array}$ & $\begin{array}{c}(3 \cdot 2-4 \cdot 2) \times 10^{5} \\
<10,<10\end{array}$ & $\begin{array}{c}(2 \cdot 1-2 \cdot 2) \times 10^{5} \\
<10,<10\end{array}$ \\
$\begin{array}{l}\text { Heated at } 70^{\circ} \mathrm{C} \text { for } \\
20 \mathrm{~min} .\end{array}$ & $<10,<10$ & $<10,<10$ & $<10,<10$ & $<10,<10$ \\
$\begin{array}{l}\text { Heated at } 80^{\circ} \mathrm{C} \text { for } \\
20 \mathrm{~min} .\end{array}$ & & & \\
\hline
\end{tabular}

* The total cell count was $4.6 \times 10^{7}$ per $\mathrm{ml}$; the spore estimate was $<6.6 \times 10^{3}$ per ml. (No spores seen in over 7000 cells counted.)

$\dagger \mathrm{EBA}=10$ per cent. equine blood agar; $\mathrm{EBAIF}=\mathrm{EBA}$ sprinkled with iron filings; $\mathrm{CDEBA}=\mathrm{EBA}$ supplemented with cysteine and dithiothreitol; CDEBAIF = CDEBA sprinkled with iron filings. Colonies on CDEBAIF were slightly more haemolytic than on the other media.

$\$$ No growth obtained from $0.1 \mathrm{ml}$ of an undiluted sample.

The effect of iron filings and the cysteine/dithiothreitol system on the surface growth of various anaerobes

The quantitative recovery of each test organism was compared on the following four media used in parallel: (i) EBA; (ii) EBA with iron filings sprinkled 
on the surface of seeded plates (EBAIF); (iii) CDEBA; and (iv) CDEBA with iron filings (CDEBAIF). With the exception of $C$. oedematiens types $A, B$ and $\mathrm{D}$, the other clostridia tested in the present study showed no qualitative or

TABLE IV

Viability of duplicate samples of a 5-hr CMB culture of Clostridium oedematiens type $A^{*}$ before and after heating at $70^{\circ} \mathrm{C}$ and at $80^{\circ} \mathrm{C}$ with recovery on different media

\begin{tabular}{|c|c|c|c|c|}
\hline \multirow{2}{*}{$\begin{array}{l}\text { Treatment } \\
\text { of sample }\end{array}$} & \multicolumn{4}{|c|}{ Surface viable count per $\mathrm{ml}$ on } \\
\hline & $\mathrm{EBA} \dagger$ & EBAIF $\dagger$ & CDEBA $\dagger$ & CDEBAIF $\dagger$ \\
\hline Nil & $(4 \cdot 8-5 \cdot 1) \times 10^{5}$ & $(1 \cdot 7-2 \cdot 1) \times 10^{5}$ & $(1 \cdot 0-1 \cdot 2) \times 10^{6}$ & $(1 \cdot 0-1 \cdot 4) \times 10^{5}$ \\
\hline $\begin{array}{l}\text { Heated at } 70^{\circ} \mathrm{C} \text { for } \\
20 \mathrm{~min} .\end{array}$ & $(1 \cdot 20-1 \cdot 12) \times 10^{4}$ & $(6 \cdot 6-9 \cdot 8) \times 10^{3}$ & $(1 \cdot 1-1 \cdot 4) \times 10^{4}$ & $(6 \cdot 9-9 \cdot 5) \times 10^{3}$ \\
\hline $\begin{array}{l}\text { Heated at } 80^{\circ} \mathrm{C} \text { for } \\
20 \mathrm{~min} .\end{array}$ & $(7 \cdot 5-8 \cdot 2) \times 10^{3}$ & $(6.6-6.9) \times 10^{3}$ & $(6 \cdot 7-8 \cdot 3) \times 10^{3}$ & $(7 \cdot 1-8 \cdot 3) \times 10^{3}$ \\
\hline
\end{tabular}

* The total cell count was $2.9 \times 10^{6} \mathrm{per} \mathrm{ml}$; the spore estimate was $7.9 \times 10^{3}$ per ml.

$\dagger \mathrm{EBA}=10$ per cent. equine blood agar; $\mathrm{EBAIF}=\mathrm{EBA}$ sprinkled with iron filings; $\mathrm{CDEBA}=\mathrm{EBA}$ supplemented with cysteine and dithiothreitol; CDEBAIF $=$ CDEBA sprinkled with iron filings.

$\log _{10}$ number of viable organisms

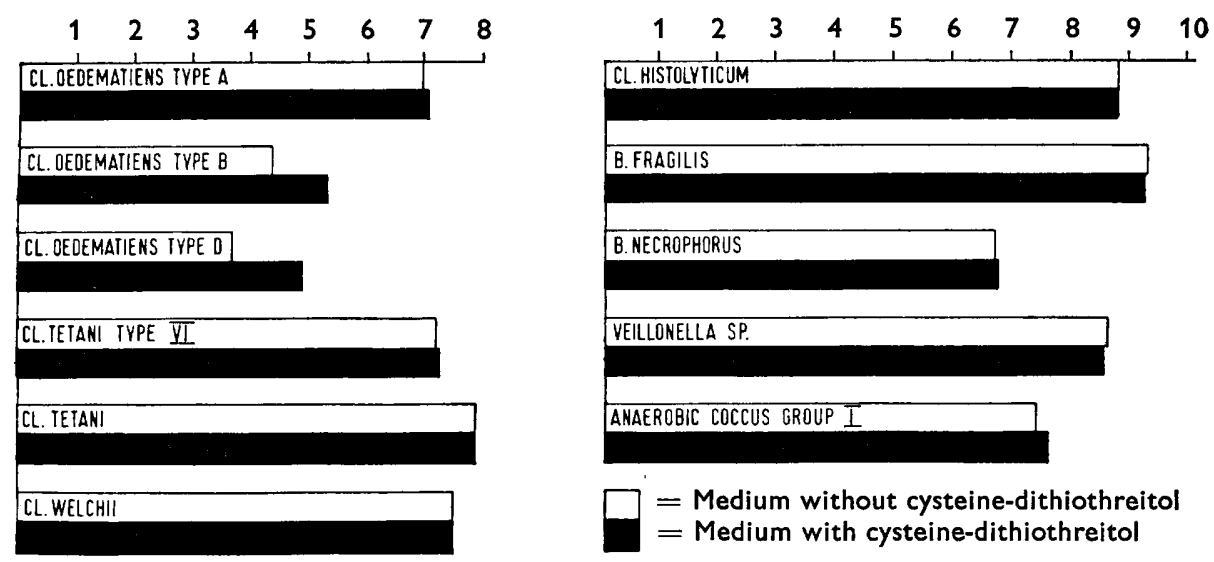

FIGURE.-A comparison of the viable counts* obtained from replicate inocula of test anaerobes grown in parallel on the surface of media with and without the cysteine-dithiothreitol system.

* Counts are expressed as $\log _{10}$ no. of viable organisms per $\mathrm{ml}$ of the test culture. In this series, each result is the mean of at least three counts obtained from separate plates seeded with a dilution that yielded 100-700 discrete colonies.

quantitative enhancement of growth attributable to the presence of the cysteinedithiothreitol system or the iron filings, separately or in combination (see tables I-IV). In the case of $\mathrm{Cl}$. oedematiens type A, the cysteine-dithiothreitol system gave minimal improvement but iron filings produced a slightly inhibitory effect (table IV). 
The growth of a wider range of anaerobic organisms was compared on EBA medium with and without the cysteine-dithiothreitol system; the results are summarised in the figure. It can be seen that, apart from the $\mathrm{Cl}$. oedematiens group, the only other organism to show any enhancement of growth was an anaerobic coccus, and here the effect was small. Several aerobic organisms were also tested and no enhancement of growth occurred on CDEBA as compared with EBA.

The recovery of $C l$. histolyticum was compared in parallel on various media, under aerobic and anaerobic conditions. Recovery was not improved in the presence of iron filings or the cysteine-dithiothreitol system. It is of interest that marginally better counts were obtained when the media were incubated aerobically: from an inoculum estimated to contain more than $5 \times 10^{8}$ organisms per $\mathrm{ml}$, and $8 \cdot 8 \times 10^{7}$ spores per $\mathrm{ml}$, surface viable counts of $8 \cdot 3 \times 10^{8}$ organisms per $\mathrm{ml}$ were obtained under aerobic conditions, and $5 \cdot 0-6 \cdot 2 \times 10^{8}$ organisms per $\mathrm{ml}$ under anaerobic conditions.

\section{Discussion}

It was possible to subculture on solid media significantly more organisms from liquid cultures of the common pathogenic clostridia than could be accounted for by the number of spores in the original sample. Exposure of cultures to heat at $70^{\circ} \mathrm{C}$ to $80^{\circ} \mathrm{C}$ for $20 \mathrm{~min}$. considerably reduced the surface viable counts of young cultures; this indicates either inactivation of vegetative cells or of immature heat-sensitive spores. In a typical experiment, an untreated sample of fluid culture yielded $5 \cdot 5-6 \cdot 5 \times 10^{7}$ colony-forming units per $\mathrm{ml}$; had these been derived from immature heat-sensitive spores, the spores would have been detectable by microscopy. Yet spores were not seen in over 1000 cells counted and no forespore forms were observed. Thus there is evidence that vegetative cells formed the major contribution to the surface viable counts. When the initial proportion of spores in a culture was high, as in the case of a 21-hr culture of $\mathrm{Cl}$. histolyticum, pasteurisation produced only a slight reduction in the viable count.

In young test cultures of two strains of $\mathrm{Cl}$. welchii and one of $\mathrm{Cl}$. tetani, the virtually complete inactivation produced by pasteurisation indicates that carryover of mature spores from the original inoculum did not occur. In a young culture of $\mathrm{Cl}$.oedematiens type A, the observed heat resistance suggests that there was a significant carry-over of mature spores, but the pasteurised viable counts were still much lower than the unpasteurised counts. The results obtained with a young culture of $\mathrm{Cl}$. septicum are more difficult to interpret. There is no doubt that vegetative cells formed the significantly viable component of the inoculum, but the survival of spores at $70^{\circ} \mathrm{C}$ and their inactivation at $80^{\circ} \mathrm{C}$ implies either that mature spores of this strain were relatively heat-sensitive or that significant sporulation occurred within $5 \mathrm{hr}$ so that immature spores of low heat resistance were present.

It is possible to recover vegetative cells in addition to spores quantitatively from laboratory cultures of clostridia. In fact, especially in young cultures, vegetative cells contribute very much more to the surface viable counts than do 
spores. Our findings are of particular significance in relation to the observations of Smith and MacIver (1969) that vegetative forms of Cl. tetani develop from a spore inoculum and persist for up to 9 days in the muscles of experimentally infected guinea-pigs and that virtually no heat-resistant spores seemed to be present in such lesions. The concept of the "significantly viable particle" (Collee et al., 1971) may also be valid in the case of natural infection, if the work of Garcia and McKay (1969) on the persistence of Cl. septicum in soil is applicable to wound infection.

These findings are of significance in the laboratory diagnosis of gas gangrene, and suggest that the clinical bacteriologist may recover satisfactory numbers of pathogenic clostridia, even when these are in the vegetative form, by the use of traditional procedures. However, the vegetative forms must not be inactivated by heat, delay in transit or the use of selective media.

Selective culture techniques involve heat, or the use of antibiotics such as neomycin (Lowbury and Lilly, 1955; Willis and Hobbs, 1959), and cycloserine (Füzi and Csukas, 1969). Although standard textbooks clearly advise that attempts to isolate sporing anaerobes should be made by culturing unheated as well as heated material (Wilson and Miles, 1964; Cruickshank, 1968; Willis, 1969), there is a danger that undue reliance may be placed on the use of heat as a selective agent. Moreover, these intentional selection procedures are often combined with the unintentional selection produced by exposure of specimens to air and to drying through delay in their transport from patient to laboratory. The fact that vegetative cells of these anaerobes can be recovered on readily available media, with routine anaerobic techniques, suggests that it may not be necessary to use special anaerobic cabinets or gas-flushing procedures to recover them from clinical specimens.

From the results of earlier work with $\mathrm{Cl}$. oedematiens (Collee et al.), it seemed that the use of iron filings or of media containing cysteine and dithiothreitol might enhance the growth of other anaerobes as well, but this does not appear to be the case. The use of a modification of Moore's medium (CDEBA) had little or no effect on the growth of the other organisms tested. It therefore appears that either $\mathrm{Cl}$. oedematiens is unique in its requirements for these factors, or that it is more demanding in its requirements for anaerobiosis than other organisms tested, or both. The general use of the iron-filings technique or the addition of cysteine and dithiothreitol as a routine to blood agar media for the isolation of anaerobes from clinical material is therefore not recommended; in some cases inhibition of growth may even result. Nevertheless, it may be worth while to determine whether similar specific factors operate to promote the growth of other anaerobes of clinical importance, notably $\mathrm{Cl}$. tetani.

\section{SUMMARY}

The surface growth of several species of clostridia was assessed in terms of the contribution made to the total viable count by spores and vegetative cells respectively. In some cases a large proportion of the surface count was derived from vegetative cells. This conclusion is based on the finding that in many cases 
the viable count considerably exceeded the maximum estimates for the number of spores in the inocula. Thus vegetative cells may be the significantly viable particles in the surface growth of common pathogenic clostridia. In general, good recovery of the anaerobes tested was obtained with traditional methods.

The possibility that the growth of clinically important anaerobes might be enhanced by the supplementation of 10 per cent. equine blood agar with either (i) sterile iron filings sprinkled on to seeded plates, or (ii) a development of Moore's cysteine-dithiothreitol system, was explored. There was no evidence that enhancement occurred, except with organisms of the $\mathrm{Cl}$. oedematiens group.

I am indebted to Dr J. G. Collee for his enthusiastic support and helpful criticism, and to Mr R. Brown for his invaluable technical assistance. We thank the Agricultural Research Council for the financial support (Grant AG 15/57) that made this work possible. The present support of the Medical Research Council (Grant G 971/113/B) for the development of these studies is gratefully acknowledged.

\section{REFERENCES}

Collee, J. G., Rutrer, J. M., AND WATt, B. 1971. The significantly viable particle: a study of the subculture of an exacting sporing anaerobe. J. Med. Microbiol., 4, 271.

Cruickshank, R. 1968. Medical microbiology, 11th ed. (revised reprint), Edinburgh and London.

Drasar, B. S., AND Crowther, J. S. 1971. The cultivation of human intestinal bacteria. In Isolation of anaerobes (Soc. Appl. Bact. Tech. Series no. 5), edited by D. A. Shapton and R. G. Board, London and New York, p. 93.

FüZI, M., AND Csukas, ZsuzsanNa 1969. New selective medium for the isolation of Clostridium perfringens. Acta microbiol. hung., 16, 273.

Garcia, M. M., AND McKay, K. A. 1969. On the growth and survival of Clostridium septicum in soil. J. Appl. Bact., 32, 362.

Hungate, R. E. 1950. The anaerobic mesophilic cellulolytic bacteria. Bact. Rev., 14, 1.

Lowbury, E. J. L., AND LILly, H. A. 1955. A selective plate medium for Cl. welchii. J. Path. Bact., 70, 105.

MOORE, W. B. 1968. Solidified media suitable for the cultivation of Clostridium novyi type B. J. Gen. Microbiol., 53, 415.

Smith, J. W. C., AND MacIVer, A. G. 1969. Studies in experimental tetanus infection. J. Med. Microbiol., 2, 385.

Williams, KathleEN, aNd Willis, A. T. 1970. A method of performing surface viable counts with Clostridium tetani. J. Med. Microbiol., 3, 639.

WiLLIS, A. T. 1969. Clostridia of wound infection, London, p. 20.

WILlis, A. T., AND HoBBs, G. 1959. Some new media for the isolation and identification of clostridia. J. Path. Bact., 77, 511.

Willis, A. T., and Williams, Kathleen 1970. Some cultural reactions of Clostridium tetani. J. Med. Microbiol., 3, 291.

Wilson, G. S., AND Miles, A. A. 1964. Topley and Wilson's Principles of bacteriology and immunity, 5th ed., London, p. 2129. 